\title{
Mathematical Modelling of Bioethanol Production from Raw Sugar Beet Cossettes in a Horizontal Rotating Tubular Bioreactor
}

\author{
Mladen Pavlečíc ${ }^{1, *(\mathbb{D})}$, Mario Novak ${ }^{1}$, Antonija Trontel ${ }^{1}{ }^{(\mathbb{D}}$, Nenad Marđetko $\left.^{1} \mathbb{(}\right)$, Marina Grubišić ${ }^{1}$, \\ Blanka Didak Ljubas ${ }^{1}$, Vlatka Petravić Tominac ${ }^{1}$, Rozelindra Čož Rakovac ${ }^{2}$ and Božidar Šantek ${ }^{1}$ (I) \\ 1 Department of Biochemical Engineering, Faculty of Food Technology and Biotechnology, \\ University of Zagreb, Pierottijeva 6, 10000 Zagreb, Croatia; mnovak@pbf.hr (M.N.); atrontel@pbf.hr (A.T.); \\ nmardetko@pbf.hr (N.M.); mgrubisic@pbf.hr (M.G.); bljubas@pbf.hr (B.D.L.); vpetrav@pbf.hr (V.P.T.); \\ bsantek@pbf.hr (B.Š.) \\ 2 Institute Rudjer Bošković, ZCI BioCroPro Bioprospecting of Adriatic Sea, Bijenička Cesta 54, \\ 10000 Zagreb, Croatia; rrakovac@irb.hr \\ * Correspondence: mpavlecic@pbf.hr; Tel.: +38-51-4605-166
}

Citation: Pavlečić, M.; Novak, M.; Trontel, A.; Marđetko, N.; Grubišić, M.; Ljubas, B.D.; Tominac, V.P.; Rakovac, R.Č.; Šantek, B.

Mathematical Modelling of Bioethanol Production from Raw Sugar Beet Cossettes in a Horizontal Rotating Tubular Bioreactor.

Fermentation 2022, 8, 13.

https://doi.org/10.3390/

fermentation 8010013

Academic Editors: Nhuan Nghiem and Taehyun Kim

Received: 8 December 2021

Accepted: 28 December 2021

Published: 30 December 2021

Publisher's Note: MDPI stays neutral with regard to jurisdictional claims in published maps and institutional affiliations.

Copyright: (c) 2021 by the authors. Licensee MDPI, Basel, Switzerland. This article is an open access article distributed under the terms and conditions of the Creative Commons Attribution (CC BY) license (https:// creativecommons.org/licenses/by/ $4.0 /)$.

\begin{abstract}
Alternative to the use of fossil fuels are biofuels (e.g., bioethanol, biodiesel and biogas), which are more environmentally friendly and which can be produced from different renewable resources. In this investigation, bioethanol production from raw sugar beet cossettes (semi-solid substrate) by yeast Saccharomyces cerevisiae in a horizontal rotating tubular bioreactor (HRTB) was studied. Obtained results show that HRTB rotation mode (constant or interval) and rotation speed have considerable impact on the efficiency of bioethanol production in the HRTB. The main goal of this research was to develop a non-structural mathematical model of bioethanol production from raw sugar beet cossettes in the HRTB. The established mathematical model of bioethanol production in the HRTB describes substrate utilization and product formation (glycerol, ethanol and acetate) and presumes negative impact of high substrate concentration on the working microorganism (substrate inhibition) by using Andrews inhibition kinetics. All simulations of bioethanol production in the HRTB were performed by using Berkeley Madonna software, version 8.3.14 (Berkeley Madonna, Berkeley, CA, USA). The established non-structural bioprocess model describes relatively well the bioethanol production from raw sugar beet cossettes in the HRTB.
\end{abstract}

Keywords: bioethanol; sugar beet cossettes; horizontal rotating tubular bioreactor; mathematical modelling; Andrews model

\section{Introduction}

Today, when the demand for energy is constantly increasing and environmental pollution caused by fossil fuels usage is on the rise, an alternative is necessary. Bioethanol among other biofuels (biodiesel, biogas) can replace fossil fuel usage and contribute to a cleaner and safer environment. Interesting enough, so far, it has been shown that several different feed stocks can be used for its production [1-4] with promising results. In 2020, world bioethanol production is still based on corn and sugarcane as the most often used raw materials. Corn represents $62 \%$ (ca. 62 millions $\mathrm{m}^{3}$ ), sugarcane $30 \%$ (ca. 30 millions $\mathrm{m}^{3}$ ), sugar beet and manioc $7 \%$ (ca. 7 millions $\mathrm{m}^{3}$ ) and all other raw materials $1 \%$ (ca. 1 million $\mathrm{m}^{3}$ ) [5]. For industrial bioethanol production, the most often used bioprocess conduction modes are fed batch, repeated batch or continuous mode. Semi-solid or solid state bioethanol production systems are related to the bioprocess with very high gravity fermentation media $[6,7]$. These bioethanol production systems are not often present at industrial scale due to their substrate or ethanol inhibitions, which have to be overcome to establish a stable bioethanol production system [8]. In Brazil, bioethanol production is based on the sugar 
cane and in North America on corn as raw materials [9]. In Europe, the sugar [10-12] and starch [8] containing raw materials are still the main raw materials for industrial bioethanol production. Sugar factories often redirect surplus of sugar beet into bioethanol production to achieve the sustainability of sugar production. The major cost of sugar production is related to the transport and availability of sugar beet in the surrounding of sugar factories. The current equipment of sugar factories produces different intermediates of sugar beet processing (e.g., thin (15-18\% sugar) or thick (65-67\% sugar) sugar beet juice as well as by-products (e.g., molasses $\approx 50 \%$ sugar) ) that can be used for bioethanol production [13]. However, production of these intermediates in a classic bioethanol production system is related to the main energy and water consuming operations such as sugar extraction from sugar beet cossettes, sugar juice concentration by evaporation, ethanol distillation, and distillers mash concentration and drying. These processes significantly affect the energy input/output ratio as well as water consumption, and therefore they have direct impact on the ecological sustainability of bioethanol production. In the semi-solid bioethanol production system, sugar extraction by hot water and sugar juice concentration by evaporation can be avoided, and therefore considerable reduction in energy and water consumption can be achieved. Furthermore, reduced consumption of cooling water and energy for ethanol distillation, as well as decreased volume of fermentation stillage due to the reduced volume of fermentation broth, can be obtained [14,15]. Additionally, it is even possible to use non sterilized sugar beet cossettes to additionally reduce energy demand at the beginning of bioethanol production. However, this can have a dual effect due to the fact that sugar beet naturally contains many different naturally occurring microorganisms [16,17]. Some of them, due to improper storage or higher temperature during harvest, can contribute to spoilage and loss of the sugar, which can lead to lower ethanol yields and productivity [18]. Sugar losses vary, and in literature it is reported that these losses can be in the range of $0.02-0.66 \% w / w$, respectively $[19,20]$. The quality of bioethanol produced from sugar beet is characterized by the lower content of fermentation by-products (e.g., higher alcohols) compared with the fermentation of starch containing raw materials. Higher concentration of by-products in unpurified ethanol reduces its price and can cause fast deterioration of molecular sieves for ethanol dehydration [15,21]. Mathematical models are very useful tool for the prediction of bioprocess performance under new experimental conditions and also additional bioprocess optimization.

In this paper, the non-structural bioprocess model of bioethanol production from raw sugar beet cossettes (semi-solid substrate) in the HRTB is presented. This mathematical model describes substrate utilization, products formation (ethanol, glycerol and acetic acid) and negative impact of high sugar concentration on a working microorganism by using the Andrews kinetic model. It is based on experimental data obtained in our research of bioethanol production in the HRTB [16]. So far, only a few mathematical models have been developed describing bioethanol production from the intermediates of sugar beet processing $[22,23]$.

\section{Materials and Methods}

\subsection{Bioethanol Production in the HRTB}

In our previous research, a series of experiments in the HRTB (Rosing, Zagreb, Croatia) was performed in order to evaluate the possibility of using semi-solid substrate (raw sugar beet cossettes) for bioethanol production by using yeast $S$. cerevisiae (yeast strain isolated from sugar factory; Culture collection of the Faculty of Food Technology and Biotechnology University of Zagreb; YSLZ-01) as working microorganism [16]. The HRTB is actually a tube $0.6 \mathrm{~m}$ long and $0.25 \mathrm{~m}$ wide with a total volume of $30 \mathrm{~L}$. Inside the bioreactor there are two paddles mounted symmetrically opposite each other. Their length is the same as the length of the bioreactor, while their width is $0.04 \mathrm{~m}$. The bioreactor was placed on bearings that enable rotation of the whole bioreactor. Furthermore, the HRTB is additionally equipped with a regulation system that enables continuous (constant) or interval rotation with different rotation/stagnation times. The inoculum for HRTB 
inoculation was prepared in Erlenmeyer flasks (ratio medium/total volume $=0.4$ ) on the raw sugar beet juice (ca. $150 \mathrm{~g} \mathrm{~L}^{-1}$ of sugar) with the addition of $1 \mathrm{~g} \mathrm{~L}^{-1}$ of $\mathrm{NH}_{4} \mathrm{H}_{2} \mathrm{PO}_{4}$ (Sigma Aldrich, St. Louis, MO, USA), as an additional source of phosphate and nitrogen, in order to support yeast growth and its physiological activity [16]. The flasks were cultivated on a rotary shaker (rotation speed of $100 \mathrm{~min}^{-1}$ ) for $18 \mathrm{~h}$ at $28^{\circ} \mathrm{C}$. The study of bioethanol production in the HRTB was also characterized by $\mathrm{NH}_{4} \mathrm{H}_{2} \mathrm{PO}_{4}$ addition $\left(1 \mathrm{~g} \mathrm{~kg}^{-1}\right.$ of raw sugar beet cossettes). Prior to the addition of raw sugar beet cossettes and yeast inoculation, the bioreactor was sterilized at $121^{\circ} \mathrm{C}$ for $20 \mathrm{~min}$. In this research, bioethanol production was studied by different HRTB operational conditions (Table 1). In the first part of the investigation, the impact of constant HRTB rotation on the bioethanol production was examined by varying the speed from 5 to $15 \mathrm{~min}^{-1}$. In the second part of the investigation, bioethanol production was studied by interval HRTB rotation (3-15 min per hour; rotation speed 5-15 $\left.\mathrm{min}^{-1}\right)$. In the first two sets of experiments, the HRTB was filled with $5 \mathrm{~kg}$ of unsterile raw sugar beet cossettes and inoculated with $1 \mathrm{~L}$ of yeast suspension $(16.67 \%$ $v / w$ raw sugar beet cossettes). In the third part of investigation, the effect of different working volume (ratio between the working $\left(V_{\mathrm{W}}\right)$ and total $\left(V_{\mathrm{T}}\right)$ bioreactor volume) of HRTB on bioethanol production was studied. In these experiments, the mass of raw sugar beet cossettes in the HRTB was changed in the range of 5-17.5 kg. Depending on the mass of initial sugar beet cossettes, the volume of yeast inoculum varied but always remained $16.67 \% v / w$. The study of bioethanol production in the HRTB was performed at room temperature without $\mathrm{pH}$ value correction. Bioethanol production in the HRTB was conducted by all combinations of operational parameters until ethanol concentration reached approximately constant level in the period of at least $48 \mathrm{~h}$. During the bioprocess, broth samples were taken, and their constituents were determined by HPLC (Shimadzu, Kyoto, Japan). All experiments in the HRTB were at least repeated, and the standard deviation of all measurements was in the range of experimental error (below 4.8\%) [16].

Table 1. Bioprocess efficiency parameters obtained during bioethanol production in the HRTB under different operational conditions.

\begin{tabular}{|c|c|c|c|}
\hline \multirow{2}{*}{$\begin{array}{l}\text { HRTB Operational } \\
\text { Conditions }\end{array}$} & \multicolumn{3}{|c|}{ Bioprocess Efficiency Parameters } \\
\hline & $\begin{array}{l}Y_{\text {EtOH/S }} \\
\left(g_{g^{-1}}\right)\end{array}$ & $\begin{array}{c}E \\
(\%)\end{array}$ & $\begin{array}{c}\operatorname{Pr} \\
\left(\mathrm{g} \mathrm{L}^{-1} \mathrm{~h}^{-1}\right)\end{array}$ \\
\hline \multicolumn{4}{|c|}{ Constant HRTB rotation mode } \\
\hline $5 \mathrm{rpm}$ & 0.27 & 50.20 & 0.247 \\
\hline $10 \mathrm{rpm}$ & 0.19 & 35.20 & 0.185 \\
\hline $15 \mathrm{rpm}$ & 0.26 & 49.30 & 0.196 \\
\hline \multicolumn{4}{|c|}{ Interval HRTB rotation mode } \\
\hline $3 \mathrm{~min} ; 5 \mathrm{rpm}$ & 0.36 & 66.90 & 0.832 \\
\hline $6 \mathrm{~min} ; 5 \mathrm{rpm}$ & 0.44 & 81.80 & 0.682 \\
\hline $9 \mathrm{~min} ; 5 \mathrm{rpm}$ & 0.35 & 65.00 & 0.613 \\
\hline $12 \mathrm{~min} ; 5 \mathrm{rpm}$ & 0.43 & 79.90 & 0.769 \\
\hline $15 \mathrm{~min} ; 5 \mathrm{rpm}$ & 0.26 & 48.30 & 0.497 \\
\hline $3 \mathrm{~min} ; 10 \mathrm{rpm}$ & 0.40 & 74.30 & 0.552 \\
\hline $6 \mathrm{~min} ; 10 \mathrm{rpm}$ & 0.23 & 42.70 & 0.357 \\
\hline $9 \mathrm{~min} ; 10 \mathrm{rpm}$ & 0.35 & 65.00 & 0.812 \\
\hline $12 \mathrm{~min} ; 10 \mathrm{rpm}$ & 0.25 & 46.50 & 0.665 \\
\hline $15 \mathrm{~min} ; 10 \mathrm{rpm}$ & 0.33 & 60.70 & 0.583 \\
\hline $3 \mathrm{~min} ; 15 \mathrm{rpm}$ & 0.35 & 64.30 & 0.934 \\
\hline $6 \mathrm{~min} ; 15 \mathrm{rpm}$ & 0.31 & 57.60 & 0.327 \\
\hline
\end{tabular}


Table 1. Cont.

\begin{tabular}{|c|c|c|c|}
\hline \multirow{2}{*}{$\begin{array}{l}\text { HRTB Operational } \\
\text { Conditions }\end{array}$} & \multicolumn{3}{|c|}{ Bioprocess Efficiency Parameters } \\
\hline & $\begin{array}{l}\mathrm{Y}_{\mathrm{EtOH} / \mathrm{S}} \\
\left(\mathrm{g} \mathrm{g}^{-1}\right)\end{array}$ & $\begin{array}{c}\mathrm{E} \\
(\%)\end{array}$ & $\begin{array}{c}\operatorname{Pr} \\
\left(\mathrm{g} \mathrm{L}^{-1} \mathrm{~h}^{-1}\right)\end{array}$ \\
\hline $9 \mathrm{~min} ; 15 \mathrm{rpm}$ & 0.32 & 58.70 & 0.606 \\
\hline $12 \mathrm{~min} ; 15 \mathrm{rpm}$ & 0.47 & 87.36 & 0.618 \\
\hline $15 \mathrm{~min} ; 15 \mathrm{rpm}$ & 0.22 & 40.90 & 0.332 \\
\hline \multicolumn{4}{|c|}{ Interval HRTB rotation mode (12 min; $15 \mathrm{rpm})$ - different initial mass of sugar beet cossettes } \\
\hline $10.0 \mathrm{~kg}$ & 0.45 & 83.64 & 0.560 \\
\hline $12.5 \mathrm{~kg}$ & 0.38 & 70.63 & 0.312 \\
\hline $15.0 \mathrm{~kg}$ & 0.37 & 68.77 & 0.548 \\
\hline $17.5 \mathrm{~kg}$ & 0.37 & 68.77 & 0.552 \\
\hline
\end{tabular}

\subsection{Mathematical Modelling of Bioethanol Production in the HRTB}

The developed bioprocess model describes the changes in concentration of biomass and main fermentation products detected in all experiments: ethanol, glycerol and acetic acid. This mathematical model was developed by using computing Berkeley Madonna software, version 8.3.14 (Berkeley Madonna, Berkeley, CA, USA). Generally, the kinetic parameters of the developed model can be divided into two groups: fixed and adjustable. The values of fixed and adjustable model parameters are presented in Tables 2 and 3.

Table 2. List and values of fixed mathematical model parameters.

\begin{tabular}{|c|c|c|c|c|c|c|}
\hline Parameter & $\begin{array}{c}Y_{X / S} \\
\left(g^{-1}\right)\end{array}$ & $\begin{array}{l}\mathrm{Y}_{\mathrm{EtOH} / \mathrm{S}} \\
\left(\mathrm{g} \mathrm{g}^{-1}\right)\end{array}$ & $\begin{array}{l}Y_{G L Y / S} \\
\left(g^{-1}\right)\end{array}$ & $\begin{array}{l}\mathrm{Y}_{\mathrm{ACET} / \mathrm{S}} \\
\left(\mathrm{g} \mathrm{g}^{-1}\right)\end{array}$ & $\begin{array}{c}\mathrm{Ks} \\
\left(\mathrm{g} \mathrm{L}^{-1}\right)\end{array}$ & $\begin{array}{c}\mathrm{Ki} \\
\left(\mathrm{g} \mathrm{L}^{-1}\right)\end{array}$ \\
\hline Value & 0.02 & 0.50 & 0.18 & 0.28 & 6.07 & 20.00 \\
\hline
\end{tabular}

Table 3. Adjustable model parameters obtained during simulation of bioethanol production in the HRTB under different operational conditions.

\begin{tabular}{|c|c|c|c|c|c|c|}
\hline \multirow{2}{*}{$\begin{array}{l}\text { HRTB Operational } \\
\text { Conditions }\end{array}$} & \multicolumn{6}{|c|}{ Adjustable Model Parameters } \\
\hline & $\begin{array}{c}X_{k} \\
\left(g L^{-1}\right)\end{array}$ & $\begin{array}{l}\mu_{\max } \\
\left(\mathbf{h}^{-1}\right)\end{array}$ & $\begin{array}{c}q_{E t O H} \\
\left(g_{x^{-1}} h^{-1}\right)\end{array}$ & $\left(\mathrm{g}_{\mathrm{x}^{-1}}^{\mathrm{qGly}^{-1}} \mathrm{~h}^{-1}\right)$ & $\begin{array}{c}\text { qAcet } \\
\left(g_{x^{-1}} h^{-1}\right)\end{array}$ & $\begin{array}{c}k_{d} \\
\left(h^{-1}\right)\end{array}$ \\
\hline \multicolumn{7}{|c|}{ Constant HRTB rotation mode } \\
\hline $5 \mathrm{rpm}$ & 1.36 & 0.05 & 0.79 & 0.10 & 0.16 & 0.04 \\
\hline $10 \mathrm{rpm}$ & 0.71 & 0.07 & 1.10 & 0.40 & 0.29 & 0.04 \\
\hline $15 \mathrm{rpm}$ & 1.03 & 0.01 & 0.27 & 0.63 & 0.10 & 0.04 \\
\hline \multicolumn{7}{|c|}{ Interval HRTB rotation mode } \\
\hline $3 \mathrm{~min} ; 5 \mathrm{rpm}$ & 2.82 & 0.03 & 0.88 & 0.10 & 0.03 & 0.04 \\
\hline $6 \mathrm{~min} ; 5 \mathrm{rpm}$ & 1.49 & 0.05 & 0.80 & 0.01 & 0.08 & 0.04 \\
\hline $9 \mathrm{~min} ; 5 \mathrm{rpm}$ & 1.60 & 0.11 & 0.80 & 0.05 & 0.01 & 0.04 \\
\hline $12 \mathrm{~min} ; 5 \mathrm{rpm}$ & 1.66 & 0.06 & 0.90 & 0.14 & 0.06 & 0.04 \\
\hline $15 \mathrm{~min} ; 5 \mathrm{rpm}$ & 0.70 & 0.04 & 0.78 & 0.20 & 0.15 & 0.01 \\
\hline $3 \mathrm{~min} ; 10 \mathrm{rpm}$ & 1.13 & 0.08 & 0.65 & 0.08 & 0.08 & 0.01 \\
\hline $6 \mathrm{~min} ; 10 \mathrm{rpm}$ & 1.00 & 0.09 & 0.80 & 0.27 & 0.15 & 0.04 \\
\hline $9 \mathrm{~min} ; 10 \mathrm{rpm}$ & 1.70 & 0.10 & 0.68 & 0.06 & 0.003 & 0.02 \\
\hline $12 \mathrm{~min} ; 10 \mathrm{rpm}$ & 2.63 & 0.07 & 0.57 & 0.09 & 0.04 & 0.03 \\
\hline
\end{tabular}


Table 3. Cont.

\begin{tabular}{|c|c|c|c|c|c|c|}
\hline \multirow{2}{*}{$\begin{array}{l}\text { HRTB Operational } \\
\text { Conditions }\end{array}$} & \multicolumn{6}{|c|}{ Adjustable Model Parameters } \\
\hline & $\begin{array}{c}X_{k} \\
\left(g L^{-1}\right)\end{array}$ & $\begin{array}{l}\mu_{\max } \\
\left(h^{-1}\right)\end{array}$ & $\begin{array}{c}\mathrm{qEtOH}_{\mathrm{EtOH}} \\
\left(\mathrm{g} \mathrm{g}_{\mathrm{x}}^{-1} \mathrm{~h}^{-1}\right)\end{array}$ & $\begin{array}{c}\mathrm{q}_{\text {Gly }} \\
\left(\mathrm{g} \mathrm{g}_{x} h^{-1}\right)\end{array}$ & $\underset{\left(\mathrm{g} \mathrm{g}_{x}^{-1} h^{-1}\right)}{q_{\text {Acet }}}$ & $\begin{array}{c}k_{d} \\
\left(h^{-1}\right)\end{array}$ \\
\hline $15 \mathrm{~min} ; 10 \mathrm{rpm}$ & 1.35 & 0.02 & 0.61 & 0.13 & 0.07 & 0.01 \\
\hline $3 \mathrm{~min} ; 15 \mathrm{rpm}$ & 2.10 & 0.07 & 0.75 & 0.07 & 0.05 & 0.02 \\
\hline $6 \mathrm{~min} ; 15 \mathrm{rpm}$ & 1.00 & 0.07 & 0.30 & 0.10 & 0.06 & 0.01 \\
\hline $9 \mathrm{~min} ; 15 \mathrm{rpm}$ & 1.60 & 0.09 & 0.48 & 0.09 & 0.02 & 0.02 \\
\hline $12 \mathrm{~min} ; 15 \mathrm{rpm}$ & 0.75 & 0.07 & 0.80 & 0.03 & 0.02 & 0.005 \\
\hline $15 \mathrm{~min} ; 15 \mathrm{rpm}$ & 0.80 & 0.07 & 0.82 & 0.26 & 0.17 & 0.03 \\
\hline \multicolumn{7}{|c|}{ Interval HRTB rotation mode (12 min; $15 \mathrm{rpm})$ - different initial mass of sugar beet cossettes } \\
\hline $10.0 \mathrm{~kg}$ & 0.58 & 0.07 & 0.80 & 0.18 & 0.07 & 0.007 \\
\hline $12.5 \mathrm{~kg}$ & 0.50 & 0.07 & 0.25 & 0.05 & 0.05 & 0.010 \\
\hline $15.0 \mathrm{~kg}$ & 2.00 & 0.07 & 0.13 & 0.04 & 0.01 & 0.001 \\
\hline $17.5 \mathrm{~kg}$ & 1.12 & 0.07 & 0.80 & 0.16 & 0.06 & 0.010 \\
\hline
\end{tabular}

\subsubsection{Yeast Growth during Bioethanol Production}

The growth of the yeast that was introduced by inoculum at the beginning of each experiment is defined by the following equation:

$$
\frac{d X}{d t}=\mu \times X-k_{d} \times X
$$

where specific growth rate is defined by

$$
\mu=\frac{\mu_{\max } \times \mathbf{S}}{\left(\mathbf{K s}+\mathbf{S}+\frac{\mathbf{S}^{2}}{\mathbf{K i}}\right)}
$$

The total yeast concentration $(X)$ is the result of yeast growth and yeast cell decaying $\left(k_{d}\right)$, which is presented in Equation (1). The specific growth rate of yeast cells $(\mu)$ is defined using the Andrews model, which incorporates the negative impact of high substrate concentration on biomass growth [24] (Equation (2)). Both $\mu_{\max }$ and $\mathrm{k}_{\mathrm{d}}$ are adjustable parameters, and their values were predicted by mathematical model.

\subsubsection{Products Formation during Bioethanol Production}

The two main fermentation products produced by yeast are ethanol and glycerol. During the fermentation process, air was not introduced in the HRTB, and therefore the bioprocess was considered as an anaerobic process. The formation of the ethanol is described by the following equation:

$$
\frac{\mathrm{dEtOH}}{\mathrm{dt}}=\mathrm{q}_{\mathrm{EtOH}} \times \mathrm{X}
$$

where $\mathrm{EtOH}$ represents ethanol concentration, and $\mathrm{q}_{\mathrm{EtOH}}$ is a specific rate of ethanol production $\left(\mathrm{g}_{\mathrm{EtOH}} / \mathrm{g}_{\mathrm{x}} \mathrm{h}\right)$. This parameter is also adjustable $\left(\mathrm{q}_{\mathrm{EtOH}}\right)$, and it is predicted by a model for each specific experimental setup.

In has been shown that high sugar concentrations cause osmotic stress for the yeast cells and therefore cause lower specific growth rates [25]. This phenomenon can be seen in different cultivation media and with different compounds on which yeast cells can be exposed [26,27]. It was observed that natural yeast cells' response to such a stressful condition is the production of osmoprotectant-namely, glycerol $[27,28]$. In addition to osmoprotection, glycerol can serve as an alternative carbon source, it can be included in redox regulation, and it can be used as a precursor for glycerophospholipids [29]. Glycerol 
production by yeast cells was incorporated in this model, but not its utilization in the yeast metabolism.

Glycerol production is represented by the following equation:

$$
\frac{\mathrm{dGlY}}{\mathrm{dt}}=\mathrm{q}_{\mathrm{GlY}} \times \mathrm{X}
$$

$\mathrm{q}_{\mathrm{GIY}}$ is an adjustable model parameter in Equation (4) and is predicted by the model. During bioethanol production in the HRTB, lower concentrations of acetic acid were also detected. Production of acetic acid has also been observed with many different strains of S. cerevisiae that can be used in wine production [30]. One of the possible reasons for acetate production may be an inability for yeast cells to synthesize lipids, which are important for cell membrane integrity, for which pyruvate is the precursor. The yeast cell actually may try to synthesize acetyl CoA as the precursor for lipid synthesis, but this is only possible under aerobic conditions because of lack of oxygen yeast cells can accumulate acetyl CoA, which can be very easily hydrolyzed to acetic acid [31]. It has also been seen that some strains of S. cerevisiae are able to synthesize glycerol and larger quantities of acetic acid. The reason for this are changes in carbon and NADH usage [32]. The change in acetic acid concentration during fermentation in HRTB is given by the following equation:

$$
\frac{\mathrm{dAcet}}{\mathrm{dt}}=\mathrm{q}_{\text {Acet }} \times \mathrm{X}
$$

\subsubsection{Substrate Utilization during Bioethanol Production}

The main sugar found in the sugar beet cossettes is sucrose. During ethanol fermentation, the yeast hydrolyzes sucrose to glucose and fructose with an enzyme-invertase [33]. A carbon source is used for both yeast growth and products formation. Equation (6) represents the change in substrate concentration over the ethanol production period in the HRTB:

$$
\frac{\mathrm{dS}}{\mathrm{dt}}=-\mu \times \frac{\mathrm{X}}{\mathrm{Y}_{\mathrm{X} / \mathrm{S}}}-\mathrm{q}_{\mathrm{EtoH}} \times \frac{\mathrm{X}}{\mathrm{Y}_{\mathrm{EtOH} / \mathrm{S}}}-\mathrm{q}_{\mathrm{Gly}} \times \frac{\mathrm{X}}{\mathrm{Y}_{\mathrm{Gly} / \mathrm{S}}}-\mathrm{q}_{\text {Acet }} \times \frac{\mathrm{X}}{\mathrm{Y}_{\text {Acet } / \mathrm{S}}}
$$

\subsubsection{Mathematical Model and Bioprocess Evaluation Criteria}

The established mathematical model was evaluated by calculating mean square errors between experimental and modeled values over the whole bioprocess period in the HRTB. Mean square error was calculated by Equation (7):

$$
\operatorname{MSE}=(1 / \mathrm{n}) \times \Sigma(\text { actual }- \text { forecast })^{2}
$$

$\mathrm{n}=$ number of measuring points;

$\Sigma$ = summation notation;

actual $=$ original or observed $y$-value;

forecast $=y$-value from regression.

Generally, the lower the value of errors the better the mathematical model describes experimental data. Furthermore, it has to be pointed out that the shape of the simulated curve was also taken into consideration during the evaluation of the mathematical model prediction efficiency.

Bioprocess efficiency parameters were calculated by using following equations:

$$
\begin{gathered}
\mathrm{Y}_{\mathrm{S}}=\mathrm{S}_{0}-\mathrm{S} \\
\mathrm{Y}_{\mathrm{EtOH}}=\mathrm{EtOH}-\mathrm{EtOH}_{0} \\
\mathrm{Y}_{\mathrm{EtOH} / \mathrm{S}}=\frac{\mathrm{Y}_{\mathrm{EtOH}}}{\mathrm{Y}_{\mathrm{S}}}
\end{gathered}
$$




$$
\begin{gathered}
\mathrm{E}=\frac{\mathrm{Y}_{\mathrm{EtOH} / \mathrm{S}}}{\mathrm{Y}_{\mathrm{EtOH} / \mathrm{ST}}} \times 100(\%) \\
\operatorname{Pr}=\frac{\mathrm{Y}_{\mathrm{E} t \mathrm{H}}}{\mathrm{t}}
\end{gathered}
$$

where $\mathrm{S}_{0}, \mathrm{EtOH}_{0}$-initial concentration of substrate or ethanol $\left(\mathrm{g} \mathrm{L}^{-1}\right)$; S, EtOH一final concentration of substrate or ethanol $\left(\mathrm{g} \mathrm{L}^{-1}\right) ; \mathrm{Y}_{\mathrm{S}}$-total consumption of substrates $\left(\mathrm{g} \mathrm{L}^{-1}\right)$; $\mathrm{Y}_{\mathrm{EtOH}}$ - total ethanol yield $\left(\mathrm{g} \mathrm{L}^{-1}\right) ; \mathrm{Y}_{\mathrm{EtOH} / \mathrm{S}}$ - conversion coefficient of substrate into ethanol $\left(\mathrm{g} \mathrm{g}^{-1}\right) ; \mathrm{Y}_{\mathrm{EtOH} / \mathrm{ST}}$ - theoretical conversion coefficient of substrate into ethanol $\left(\mathrm{g} \mathrm{g}^{-1}\right)$; E-bioprocess efficiency (\%), $\mathrm{Pr}$-bioprocess productivity $\left(\mathrm{g} \mathrm{L}^{-1} \mathrm{~h}^{-1}\right)$ and $\mathrm{t}$ - time (h).

\section{Results}

\subsection{Bioethanol Production in the HRTB}

Bioethanol production from non-sterilized raw sugar beet cossettes in the HRTB was studied by different bioreactor operational setup (different rotation speeds and modes) together with different initial mass of sugar beet cossettes. In summary, all conversion coefficients of substrate into ethanol $\left(\mathrm{Y}_{\mathrm{EtOH} / \mathrm{S}}\right)$, efficiencies (E), and productivities (Pr) are given in Table 1.

From the data shown in Table 1, it can be seen that the obtained bioprocess efficiency parameters are not clearly correlated with HRTB operational conditions by experiments with constant HRTB rotation mode. In cases when interval HRTB rotation mode was used, the highest bioprocess efficiency was observed by rotation of $12 \mathrm{~min}$ within one hour and rotation speed of $15 \mathrm{rpm}$. This was the highest efficiency calculated in all experimental setups. The study of ethanol production in the HRTB by constant and interval rotation mode (first two sections in Table 1) were performed with $5 \mathrm{~kg}$ of raw sugar beet cossettes. Generally speaking, it was observed that longer HRTB rotation time contributed to higher bioprocess efficiency because of better homogeneity and mass transfer in the HRTB as a consequence of longer mixing period. The rotation speed of HRTB, however, was less of importance since relatively good yields were obtained at lower and higher rotation speeds. Due to fact that the highest bioprocess efficiency $(87.36 \%)$ was obtained at interval rotation mode (12 min and $15 \mathrm{rpm}$ ), this setup was used in the final research stage where different initial masses of sugar beet cossettes were added in the HRTB. In this stage, the highest bioprocess efficiency parameters were observed by bioethanol production with $10 \mathrm{~kg}$ of raw sugar beet cossettes in the HRTB.

\subsection{Mathematical Model}

The established bioprocess model is comprised of two types of parameters: fixed parameters given in Table 2 and adjustable parameters presented in Table 3. Fixed model parameters have the same values in established mathematical models, whereas adjustable are changed during the simulation process.

Adjustable model parameters are $\mu_{\max }, \mathrm{q}_{\mathrm{EtOH}}, \mathrm{q}_{\mathrm{Gly}}, \mathrm{q}_{\mathrm{Acet}}$ and yeast cell death rate $\left(\mathrm{k}_{\mathrm{d}}\right)$. All values for adjustable parameters are given in Table 3.

Initial concentrations of ethanol, glycerol and acetic acid are different for all experiments, together with biomass concentration, which is logical because of the complexity of the substrate and initial inoculum composition in each experiment. Due to the problems with initial yeast biomass concentration determination (dispersion within the cossettes, presence of small particles from the sugar beet that influenced the experimental data), initial biomass concentration was predicted by the bioprocess model. Figure 1 shows the modelled data in cases where constant HRTB rotation mode was used (10 rpm). 


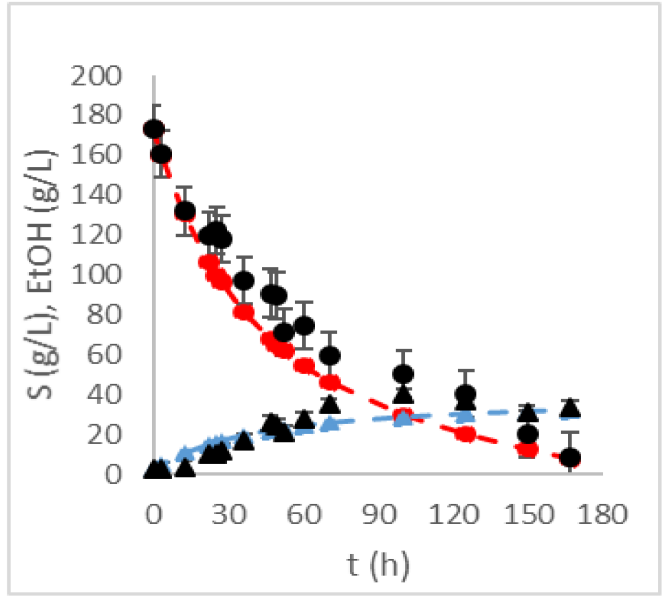

(A)

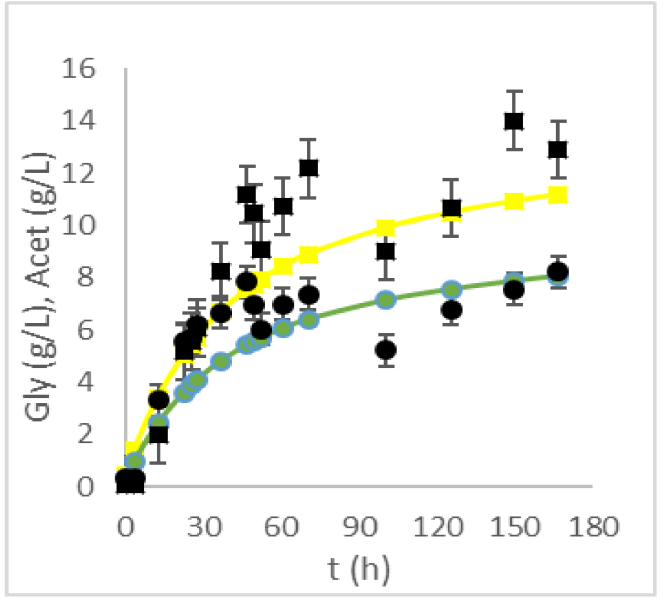

(B)

Figure 1. Comparison between experimental (no line) and model values (dashed line) for (A) substrate $(\bullet)$ and ethanol $(\mathbf{\Lambda})$ concentration and $(\mathbf{B})$ glycerol $(\mathbf{\square})$ and acetic acid $(\bullet)$ concentration obtained for experiment with constant HRTB rotation mode (10 rpm). Discrepancies between experimental data are presented as error bars.

An example of bioethanol production in the HRTB at interval rotation mode (12 min; $10 \mathrm{rpm}$ ) is presented in Figure 2, and discrepancies between modelled and experimental data are given in Table 4.

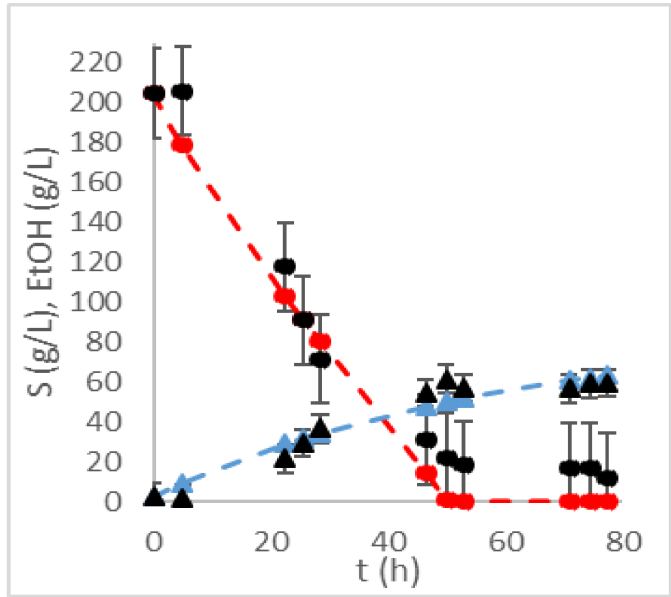

(A)

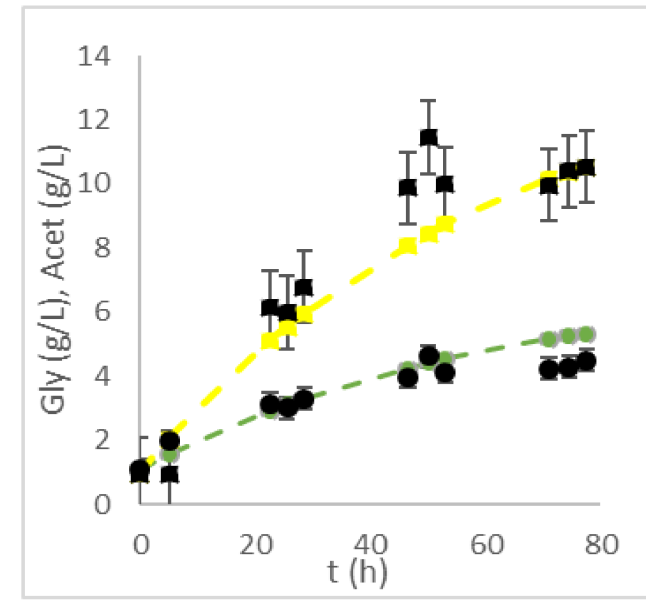

(B)

Figure 2. Comparison between experimental (no line) and model values (dashed line) for (A) substrate $(\bullet)$ and ethanol $(\boldsymbol{\Lambda})$ concentration and (B) glycerol ( $\mathbf{\square})$ and acetic acid $(\bullet)$ concentration obtained for experiment with interval HRTB rotation mode (12 min; $10 \mathrm{rpm}$ ). Discrepancies between experimental data are presented as error bars. 
Table 4. Mean square errors for bioethanol production in the HRTB under different bioreactor operational conditions.

\begin{tabular}{|c|c|c|c|c|}
\hline \multirow{2}{*}{ HRTB Operational Conditions } & \multicolumn{3}{|c|}{ MSE } & \multirow[b]{2}{*}{ Acetic Acid } \\
\hline & Substrate & Ethanol & Glycerol & \\
\hline \multicolumn{5}{|l|}{ Constant HRTB rotation mode } \\
\hline $5 \mathrm{rpm}$ & 480.60 & 53.05 & 42.70 & 0.26 \\
\hline $10 \mathrm{rpm}$ & 273.79 & 30.38 & 3.84 & 2.02 \\
\hline $15 \mathrm{rpm}$ & 629.86 & 18.83 & 15.79 & 11.83 \\
\hline \multicolumn{5}{|l|}{ Interval HRTB rotation mode } \\
\hline $3 \mathrm{~min} ; 5 \mathrm{rpm}$ & 265.64 & 29.35 & 3.56 & 1.22 \\
\hline $6 \mathrm{~min} ; 5 \mathrm{rpm}$ & 334.17 & 278.58 & 59.70 & 0.14 \\
\hline $9 \mathrm{~min} ; 5 \mathrm{rpm}$ & 75.38 & 173.65 & 14.24 & 0.54 \\
\hline $12 \mathrm{~min} ; 5 \mathrm{rpm}$ & 1468.88 & 265.26 & 3.18 & 0.49 \\
\hline $15 \mathrm{~min} ; 5 \mathrm{rpm}$ & 524.14 & 20.09 & 3.24 & 0.80 \\
\hline $3 \mathrm{~min} ; 10 \mathrm{rpm}$ & 144.53 & 1276.16 & 17.11 & 4.67 \\
\hline $6 \mathrm{~min} ; 10 \mathrm{rpm}$ & 649.08 & 505.06 & 8667.72 & 345.15 \\
\hline $9 \mathrm{~min} ; 10 \mathrm{rpm}$ & 690.02 & 4.52 & 3.15 & 0.04 \\
\hline $12 \mathrm{~min} ; 10 \mathrm{rpm}$ & 282.46 & 36.75 & 1.72 & 0.30 \\
\hline $15 \mathrm{~min} ; 10 \mathrm{rpm}$ & 171.00 & 40.83 & 2.97 & 1.94 \\
\hline $3 \mathrm{~min} ; 15 \mathrm{rpm}$ & 336.39 & 53.30 & 1.04 & 2.09 \\
\hline $6 \mathrm{~min} ; 15 \mathrm{rpm}$ & 365.11 & 27.05 & 7.42 & 4.70 \\
\hline $9 \mathrm{~min} ; 15 \mathrm{rpm}$ & 601.61 & 250.88 & 8.05 & 0.59 \\
\hline $12 \mathrm{~min} ; 15 \mathrm{rpm}$ & 562.54 & 299.83 & 27.01 & 0.30 \\
\hline $15 \mathrm{~min} ; 15 \mathrm{rpm}$ & 279.14 & 57.95 & 4.14 & 1.92 \\
\hline \multicolumn{5}{|c|}{ Interval HRTB rotation mode (12 min; $15 \mathrm{rpm})$ —different initial mass of sugar beet cossettes } \\
\hline $10.0 \mathrm{~kg}$ & 377.57 & 81.06 & 8.51 & 1.69 \\
\hline $12.5 \mathrm{~kg}$ & 460.67 & 18.69 & 27.54 & 3.60 \\
\hline $15.0 \mathrm{~kg}$ & 401.92 & 528.26 & 14.28 & 3.79 \\
\hline $17.5 \mathrm{~kg}$ & 383.48 & 374.22 & 6.20 & 1.05 \\
\hline
\end{tabular}

Results of bioethanol production in the HRTB with $17.5 \mathrm{~kg}$ of sugar beet cossettes and interval HRTB rotation mode (12 min; $15 \mathrm{rpm}$ ) are presented in Figure 3. Discrepancies between modelled and experimental data for all HRTB operational conditions are presented in Table 4. 


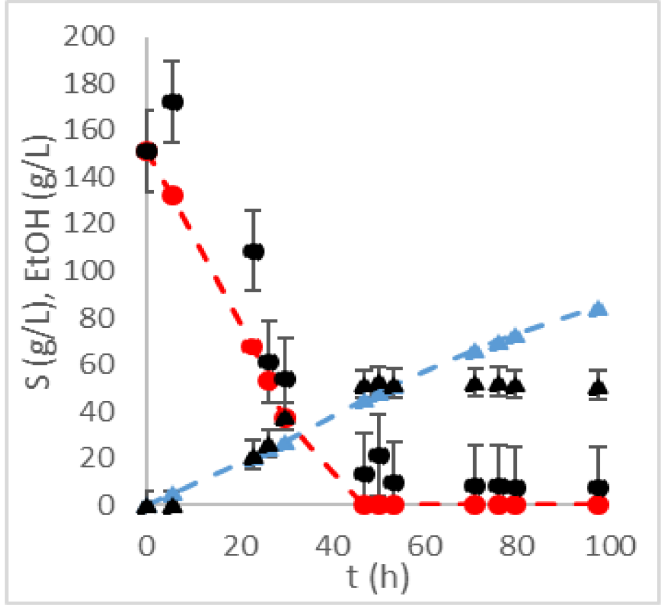

(A)

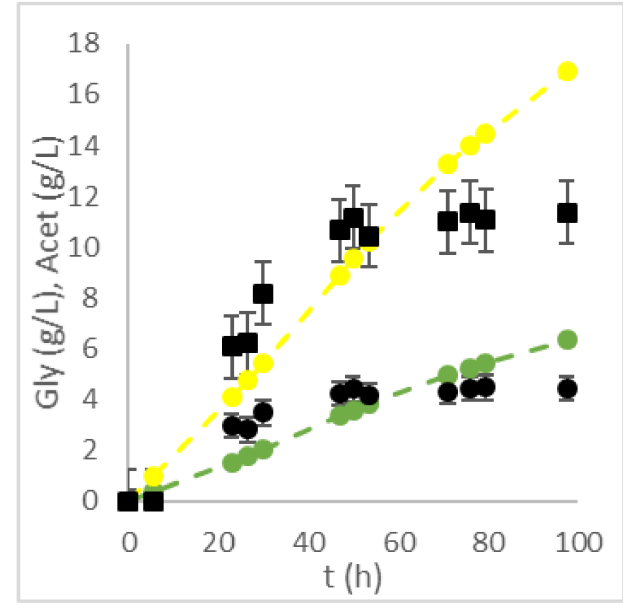

(B)

Figure 3. Comparison between experimental (no line) and model values (dashed line) for $(\mathbf{A})$ substrate $(\bullet)$ and ethanol $(\boldsymbol{\Lambda})$ concentration and (B) glycerol $(\mathbf{\square})$ and acetic acid $(\bullet)$ concentration obtained for experiment with interval HRTB rotation mode (12 min; $15 \mathrm{rpm}$ ) and $17.5 \mathrm{~kg}$ of initial mass of sugar beet cossettes. Discrepancies between experimental data are presented as error bars.

\section{Discussion}

In this paper, a mathematical model representing bioethanol production from raw sugar beet cossettes in the HRTB was developed. From the data shown in Table 1, it can be seen that the constant HRTB rotation mode with different rotation speeds did not show clear impact on bioethanol production efficiency. In cases with 5 and $15 \mathrm{rpm}$, similar bioprocess efficiency parameters were observed. However, slightly lower bioprocess efficiency parameters were observed at rotation speed of $10 \mathrm{rpm}$, probably as a consequence of raw sugar beet cossettes heterogeneity. In general, constant HRTB rotation mode is related to the lower bioethanol production efficiency. In cases when interval HRTB rotation mode was used, the highest efficiency was observed when the bioreactor rotated $12 \mathrm{~min}$ within one hour and when HRTB rotation speed was set to $15 \mathrm{rpm}$. This was the highest efficiency calculated in all experiments concerning bioethanol production $(\mathrm{E}=87.36 \%)$. Due to this fact, this HRTB operational setup was applied in the final research stage where different initial mass of sugar beet cossettes were added in the bioreactor. The highest efficiency $(83.64 \%)$ and productivity $\left(0.560 \mathrm{~g} \mathrm{~L}^{-1} \mathrm{~h}\right)$ in these experiments were obtained by bioethanol production in the HRTB with $10 \mathrm{~kg}$ of raw sugar beet cossettes (Table 1 ). The impact of bioreactor operational parameters on the bioethanol production in the HRTB was discussed in more detail earlier [16].

The mathematical model of bioethanol production from the raw sugar beet cossettes in HRTB consists of different differential equations expressing the change in yeast biomass concentration, substrate consumption and product formation over time (ethanol, glycerol and acetic acid). Due to relatively high initial sugar concentration, and during the whole fermentation process, a negative impact of substrate concentration (inhibition) on the yeast growth rate was assumed. The effect of substrate inhibition is dominant, and it mitigates the inhibitory effect of ethanol for instance. Additionally, it has been shown that sugar beet cossettes can effectively be used as a carrier (immobilizing agent) for yeast cells during ethanol production [34]. In this way, cells were in a way "protected" from an additional inhibitory effect from ethanol but not from high sugar concentrations. Specific growth rate was defined using the Andrews model, which is represented in Equation (2). The model is comprised of two types of parameters: fixed (Table 2) and adjustable (Table 3) parameters. Fixed model parameter means that it has the same value under all HRTB operational conditions, whereas adjustable parameters are slightly changed depending on the bioreactor operational conditions. Initial concentrations of ethanol, glycerol and acetic 
acid are different for all experiments, together with yeast biomass concentration, which is logical because of the complexity of the substrate (its heterogeneity) and initial inoculum composition in each experimental setup. Direct determination of yeast biomass concentration (dispersion within the cossettes, presence of small particles from the sugar beet that effected the analytical results, etc.) faced a lot of problems, and therefore its concentrations were predicted by mathematical model. However, the values of initial yeast concentration in the bioprocess model were in accordance with the data in the literature [35]. Indirect methods for determination of biomass concentrations were also developed that include physical (e.g., scanning electron microscopy, epifluorescence microscopy, flow cytometry, effluent gas composition or light reflectance), chemical and biochemical (quantification of cell-specific components (e.g., ergosterol, glucosamine, chitin, nucleic acids or proteins) or other cell parameters determination (e.g., intracellular water and total carbon content, enzymatic or immunological activity or ATP levels etc.)) methods [36-38]. However, all these methods have their own advantages and disadvantages, which have to be considered in the selection procedure for biomass determination during semi-solid (or solid) bioprocesses.

The obtained model data were compared within the same group of experiments (i.e., constant rotation mode) and also within two different operational bioreactor setups (interval rotation mode). In the case of experiments with constant HRTB rotation mode at different rotation speeds, the best bioprocess model prediction of experimental data was obtained in the experiment where bioreactor rotation speed was set at $10 \mathrm{rpm}$ (Table 4). This comparison is presented in Figure 1. However, in every experimental setup, some discrepancy between real and modelled data can be seen. One of the reasons for this difference is the heterogeneity of the sample (sugar beet cossettes). It is possible that in some samples the fermentation medium was not fully homogenous (representative), and therefore the experimental data were not quite in accordance with the predicted model values. For instance, in the case of lower rotation speed (5 rpm), the difference between experimental and model values was even greater, which might be the result of poorer mixing in comparison with the experiment with $10 \mathrm{rpm}$. It would be expected that at higher HRTB rotation speed $(15 \mathrm{rpm})$ the fermentation media would be more homogenized and that the discrepancy between experimental and model values would be lower; however, this was not the case. It is possible that with higher rotation speeds, the more liquid part of the broth was dispersed within the beet cossettes, and therefore the sample concentrations were not representative.

The second part of investigation was more focused on interval HRTB rotation mode, where the bioreactor rotated for a different period of time within one hour, together with a different rotation speed. The developed bioprocess model also relatively well describes the obtained experimental data under these HRTB operational conditions. In cases when the HRTB rotated only 3 min within $1 \mathrm{~h}$ and the rest of the time the bioreactor stood still, the best bioprocess model prediction was observed in the experiment where the lowest rotation speed was used $(5 \mathrm{rpm})$. The bioprocess model predicts lower maximal specific growth rates of the working microorganism, which is in accordance with the fact that all experiments were done under anaerobic conditions. The lowest growth rate $\left(\mu_{\max }=0.03 \mathrm{~h}^{-1}\right)$ was obtained in the experiment with the lowest rotation speed. With an increase in HRTB rotation speed, the maximum specific growth rate was raised, and it was $0.07 \mathrm{~h}^{-1}$ and $0.08 \mathrm{~h}^{-1}$ in experiments with 10 and $15 \mathrm{rpm}$, respectively. The results for highest specific product formation rates were mixed. When the bioreactor rotation speed was the lowest, it benefited faster ethanol and glycerol production $\left(\mathrm{q}_{\text {ETOH }}=0.88 \mathrm{~g} \mathrm{gx}^{-1} \mathrm{~h}^{-1}, \mathrm{qGLY}=0.10 \mathrm{~g} \mathrm{gx}^{-1} \mathrm{~h}^{-1}\right)$. The slowest acetate production rate was observed at $5 \mathrm{rpm}\left(\mathrm{q}_{\mathrm{ACET}}=0.03 \mathrm{~g} \mathrm{gx}^{-1} \mathrm{~h}^{-1}\right)$, where at 10 and $15 \mathrm{rpm}$ this parameter was almost the same $\left(\mathrm{qACET}_{\text {ACT }}=0.05 \mathrm{~g} \mathrm{gx}^{-1} \mathrm{~h}^{-1}\right)$. Increasing the duration of mixing (6 min rotation and $54 \mathrm{~min}$ resting) did influence the correlation between experimental and model data. The smallest discrepancy was observed in the experiment where bioreactor speed was set to $10 \mathrm{rpm}$. The bioprocess model predicted the highest specific growth rate for the working microorganism in this case $\left(\mu_{\max }=0.09 \mathrm{~h}^{-1}\right)$. Additionally, predicted values for initial biomass concentration in all 
three experiments were around $1 \mathrm{~g} \mathrm{~L}^{-1}$. The weakest correlation between experimental and modelled data was observed in the case of glycerol and acetate concentrations in all three experiments (Table 4). Further increase in the duration of bioreactor rotation (9 min rotation, 51 min stationary) gave similar results as the previous HRTB operational setup. Slightly lower bioprocess model prediction was observed when bioreactor rotation speed was set to 5 and $10 \mathrm{rpm}$. The best bioprocess model fitting was observed in the case where rotation was set to $15 \mathrm{rpm}$ (data not shown). The highest modelled specific growth rate was $0.11 \mathrm{~h}^{-1}$. This result was achieved at the lowest bioreactor rotation speed, and this shows that multiple factors influence the bioprocess dynamics and yeast activity. The initial biomass concentration predicted in all three models was similar and was around $1.6 \mathrm{~g} \mathrm{~L}^{-1}$. In the next series of experiments, HRTB rotation time was further prolonged to $12 \mathrm{~min}$ in a one-hour period. In all three cases, it was observed that the modelled specific growth rate was higher in comparison with experiments with lower bioreactor rotation times $\left(\mu_{\max }=0.07 \mathrm{~h}^{-1}\right)$. This can be explained by better homogenization in the HRTB and better mass transfer due to better mixing. The best results for model approximation of experimental data were obtained in the case where the bioreactor rotation speed was set to $10 \mathrm{rpm}$. The bioprocess model relatively well describes the experimental data. The mean square error calculated for this case is given in Table 4 . In cases of lower and higher rotation speed (5 and $15 \mathrm{rpm}$ ) with the same rotation/stationary phase times, there was a noticeable discrepancy, probably due to the fact that lower bioreactor rotation speed contributed to poorer homogenization. In the case of $15 \mathrm{rpm}$, it seems that a higher rotation speed caused higher liquid phase dispersion within cossettes, which also influenced the sample homogeneity. It should be noted that in the case where the bioreactor rotation speed was set to $10 \mathrm{rpm}$, our developed model most accurately described the experimental data in comparison with all fermentations. The last bioreactor operational setting was $15 \mathrm{~min}$ rotation and $45 \mathrm{~min}$ stationary phase. Additionally, three experiments were done using three different HRTB rotation speeds. The bioprocess model described relatively well the obtained experimental data. In all three experiments (5 rpm, $10 \mathrm{rpm}$ and $15 \mathrm{rpm}$ ) there was a similar discrepancy with obtained experimental data (Table 4). The highest maximum specific growth rate was observed at $15 \mathrm{rpm}\left(\mu_{\max }=0.07 \mathrm{~h}^{-1}\right)$. In addition, all three specific product synthesis rates were observed with the highest bioreactor rotation speed. Modelled values of these parameters were as follows; $\mathrm{q}_{\mathrm{EtOH}}=0.82 \mathrm{~g} \mathrm{gx}^{-1} \mathrm{~h}^{-1}$, $\mathrm{q}_{\mathrm{Gly}}=0.26 \mathrm{~g} \mathrm{gx}^{-1} \mathrm{~h}^{-1}, \mathrm{q}_{\text {Acet }}=0.17 \mathrm{~g} \mathrm{gx}^{-1} \mathrm{~h}^{-1}$, respectively. In conclusion to this part of the investigation, it seems that even lower rotation speed, when the bioreactor is rotating long enough, can ensure proper and good homogenization of the fermentation broth. It can also be concluded that $15 \mathrm{rpm}$ is the optimal bioreactor rotation speed through all different combinations of rotation/stationary phases.

In the final stage of our research, a series of experiments was performed to see if the initial mass of raw sugar beet cossettes had influence on the bioethanol yield. The experiments were conducted with $10,12.5,15$ and $17.5 \mathrm{~kg}$ of initial mass of raw sugar beet cossettes. In comparison with previous results, it was observed that the developed model fitted the experimental data less accurately, which can be explained by poorer bioreactor mixing and liquid dispersion as the initial mass of sugar beet cossettes increases. Therefore, it is necessary to optimize the bioreactor interval rotation mode conditions for higher initial mass of sugar beet cossettes in the HRTB. The discrepancy between experimental and modeled values increased with the initial mass of raw sugar beet cossettes and it was the highest for the experiment where $17.5 \mathrm{~kg}$ of sugar beet was used. The highest value of modelled parameters was observed in the case where $10 \mathrm{~kg}$ of sugar beet cossettes was used-namely, their values were as follows; $\mathrm{q}_{\mathrm{EtOH}}=0.80 \mathrm{~g} \mathrm{gx}^{-1} \mathrm{~h}^{-1}, \mathrm{qGly}_{\mathrm{G}}=0.18 \mathrm{~g} \mathrm{gx}^{-1} \mathrm{~h}^{-1}$, $\mathrm{q}_{\text {Acet }}=0.07 \mathrm{~g} \mathrm{~g}_{\mathrm{x}}{ }^{-1} \mathrm{~h}^{-1}$, respectively (Table 3).

\section{Conclusions}

On the basis of research data, it is obvious that HRTB rotation mode (constant or interval) and rotation speed have considerable impact on bioprocess performance (kinetics 
and efficiency). It was also proved that HRTB interval rotation mode is superior to constant HRTB rotation mode. Increasing the initial mass of raw sugar beet cossettes did not have any beneficial effects since the main problem was probably poor mixing together, with even more pronounced substrate inhibition. Therefore, a new investigation has to be performed in order to define the HRTB operational conditions under which bioethanol production efficiency can be improved. On the basis of the obtained results, it is clear that the established non-structural mathematical model with Andrews inhibition kinetics can be successfully used for the prediction of bioethanol production in the HRTB on a semi-solid substrate (raw sugar beet cossettes). It can be also applied for monitoring of bioethanol production in different bioreactor systems through the control and prediction of bioprocess parameters such as concentration of sugars, ethanol, lactate or other bioprocess products. Prediction of bioprocess performance and scale-up of bioethanol production systems after additional testing in larger bioreactor scales can be also accomplished by the established bioprocess model.

Author Contributions: Conceptualization, M.P.; methodology, A.T.; investigation, N.M. and B.D.L.; writing—original draft preparation, M.P.; writing—review and editing, B.Š. and M.N.; visualization, M.G. and V.P.T.; supervision, R.Č.R. and B.Š. All authors have read and agreed to the published version of the manuscript.

Funding: This research was funded by Croatian Science Foundation by project "Sustainable Production of Biochemicals from Waste Lignocellulose Containing Feedstocks" (HRZZ-IP-2018-01-9717) and by the project "Bioprospecting of the Adriatic Sea" (KK.01.1.1.01.0002).

Institutional Review Board Statement: Not applicable, exclude statement.

Informed Consent Statement: Not applicable, exclude statement.

Data Availability Statement: Exclude statement.

Conflicts of Interest: The authors declare no conflict of interest. The funders had no role in the design of the study or in the collection and interpretation of the data. Additionally, they had no influence on the writing of this paper or in the decision to publish the presented data.

\section{References}

1. Zhaoa, J.; Xua, Y.; Wang, W.; Griffin, J.; Roozeboomd, K.; Wang, D. Bioconversion of industrial hemp biomass for bioethanol production: A review. Fuel 2020, 281, 118725. [CrossRef]

2. Kumar Prasad, R.; Chatterjee, S.; Mazumder Pranab, B.; Kumar Gupta, S.; Sharma, S.; Gunvant Vairale, M.; Datta, S.; Kumar Dwivedi, S.; Kumar Gupta, D. Bioethanol production from waste lignocelluloses: A review on microbial degradation potential. Chemosphere 2019, 231, 588-606. [CrossRef]

3. Dave, N.; Selvaraj, R.; Varadavenkatesan, T.; Vinayagam, R. A critical review on production of bioethanol from macroalgal biomass. Algal Res. 2019, 42, 101606. [CrossRef]

4. Saadiah Hafid, H.; Abdul Rahman, N.A.; Md Shah, U.K.; Samsu Baharuddin, A.; Ariff, A.B. Feasibility of using kitchen waste as future substrate for bioethanol production: A review. Renew. Sustain. Energy Rev. 2017, 74, 671-686. [CrossRef]

5. Torroba, A. Liquid Biofuels Atlas. 2021, pp. 1-35. Available online: http://www.iica.int (accessed on 24 December 2021).

6. Bai, F.W.; Chen, L.J.; Anderson, W.A.; Moo-Young, M. Parameter oscillations in very high gravity medium continuous ethanol fermentation and their attenuation on multi-stage packed column bioreactor system. Biotechnol. Bioeng. 2004, 88, 558-566. [CrossRef]

7. Bai, F.W.; Anderson, W.A.; Moo-Young, M. Ethanol fermentation technologies from sugar and starch feedstocks. Biotechnol. Adv. 2008, 26, 89-105. [CrossRef]

8. Cardona, C.A.; Sánchez, Ó.J. Fuel ethanol production: Process design trends and integration opportunities. Bioresour. Technol. 2007, 98, 2415-2457. [CrossRef]

9. Giubbina, F.F.; Scaramboni, C.; De Martinis, B.S.; Godoy-Silva, D.; Mello, I.N.P.D.; Nogueira, R.F.P.; Campos, M.L.A.M. Temporal variation of ethanol in rainwater from the sugar cane belt of SãoPaulo State (Brazil). Atmos. Environ. 2019, 216, 116926. [CrossRef]

10. Kawa-Rygielska, J.; Pietrzak, W.; Regiec, P.; Stencel, P. Utilization of concentrate after membrane filtration of sugar beet thin juice for ethanol production. Bioresour. Technol. 2013, 133, 134-141. [CrossRef]

11. Vučurović, D.G.; Dodić, S.N.; Popov, S.D.; Dodić, J.M.; Grahovac, J.A. Process model and economic analysis of ethanol production from sugar beet raw juice as part of the cleaner production concept. Bioresour. Technol. 2012, 104, 367-372. [CrossRef] 
12. Tan, L.; Sun, Z.Y.; Okamoto, S.; Takaki, M.; Tang, Y.Q.; Morimura, S.; Kida, K. Production of ethanol from raw juice and thick juice of sugar beet by continuous ethanol fermentation with flocculating yeast strain KF-7. Biomass Bioenergy 2015, 81, 265-272. [CrossRef]

13. Dodić, S.; Popov, S.; Dodić, J.; Ranković, J.; Zavargo, Z.; Jevtić Mučibabić, R. Bioethanol production from thick juice as intermediate of sugar beet processing. Biomass Bioenergy 2009, 33, 822-827. [CrossRef]

14. Šantek, B.; Gwehenberger, G.; Ivančić Šantek, M.; Narodoslawsky, M.; Horvat, P. Evaluation of energy demand and the sustainability of different bioethanol production processes from sugar beet. Resour. Conserv. Recycl. 2010, 54, 872-877. [CrossRef]

15. Dziugan, P.; Balcerek, M.; Pielech-Przybylska, K.; Patelski, P. Evaluation of the fermentation of high gravity thick sugar beet juice worts for efficient bioethanol production. Biotechnol. Biofuels 2013, 6, 158. [CrossRef]

16. Pavlečić, M.; Rezić, T.; Ivančić Šantek, M.; Horvat, P.; Šantek, B. Bioethanol production from raw sugar beet cossettes in horizontal rotating tubular bioreactor. Bioprocess Biosyst. Eng. 2017, 40, 1679-1688. [CrossRef] [PubMed]

17. Lilley, K.A.; Fry, C.J.; Bailey, J.M.; Day, J.M. Comparison of aerobic heterotrophic taxa isolatedfrom four root domains of mature sugar beet (Beta vulgaris). FEMS Microbiol. Ecol. 1996, 21, 231-242. [CrossRef]

18. Li, M.; Yang, F.; Wu, X.; Yan, H.; Liu, Y. Effects of continuous cropping of sugar beet (Beta vulgaris L.) on its endophytic andsoil bacterial community by high throughput sequencing. Ann. Microbiol. 2020, 70, 39. [CrossRef]

19. Sereš, Z.; Maravic, N.; Rakic, D.; Dokic, L.J.; Nikolic, I.; Soronja-Simovic, D.; Đorđevic, M. Application of biocides in the process of sucrose extraction from sugar beet: Effect on sucrose content, number of Leuconostoc colonies and wet pulp characteristics. Food Sci. Technol. 2017, 75, 17-24. [CrossRef]

20. Kohout, K.C.; Ukowitz, C.; Reiter, D.; Zitz, U.; Moder, K.; Emerstorfer., F.; Hein, W.; Kneifel, W.; Domig, J.K. Bacterial growth dynamics and corresponding metabolite levels in the extraction area of an Austrian sugar beet factory using antimicrobial treatment. J. Sci. Food Agric. 2020, 100, 2713-2721. [CrossRef] [PubMed]

21. Kłosowski, G.; Mikulski, D.; Czupryński, B.; Kotarska, K. Characterisation of fermentation of high-gravity maize mashes with the application of pullulanase, proteolytic enzymes and enzymes degrading non-starch polysaccharides. J. Biosci. Bioeng. 2010, 109, 466-471. [CrossRef]

22. Grahovac, J.; Jokic, A.; Dodic, J.; Vucurovic, D.; Dodic, S. Modelling and prediction of bioethanol production from intermediates and byproduct of sugar beet processing using neural networks. Renew. Energy 2016, 85, 953-958. [CrossRef]

23. Dodic, M.J.; Vucurovic, G.D.; Dodic, S.N.; Grahovac, J.A.; Popov, S.D.; Nedeljkovic, N.M. Kinetic modelling of batch ethanol production from sugar beet raw juice. Appl. Energy 2012, 99, 192-197. [CrossRef]

24. Andrews, J.F. A mathematical model for the continuous culture of microorganisms utilizing inhibitory substrates. Biotechnol. Bioeng. 1968, 10, 707-723. [CrossRef]

25. Joannis-Cassan, C.; Riess, J.; Jolibert, F.; Taillandier, P. Optimization of very high gravity fermentationn process for ethanol production from industrial sugar beet syrup. Biomass Bioenergy 2014, 70, 165-173. [CrossRef]

26. Attfield, P.V.; Kletsas, S. Hyperosmotic stress response by strains of bakers' yeasts in high sugar concentration medium. Lett. Appl. Microbiol. 2001, 31, 323-327. [CrossRef] [PubMed]

27. Gomar-Alba, M.; Morcillo-Parra, M.A.; del Olmo, M.L. Response of yeast cells to high glucose involves molecular and physiological differences when compared to other osmostress conditions. FEMS Yeast Res. 2015, 15, fov039. [CrossRef]

28. Andre, L.; Hemming, A.; Adler, L. Osmoregulation in Saccharomyces cerevisiae studies on the osmotic induction of glycerol production and glycerol 3-phosphate dehydrogenase (NAD+). FEBS Lett. 1991, 286, 13-17. [CrossRef]

29. Hohmann, S. Osmotic adaptation in yeast-control of the yeast osmolyte system. Int. Rev. Cytol. 2002, 215, 149-187. [CrossRef]

30. Paraggio, M.; Fiore, C. Screening of Saccharomyces cerevisiae wine strains for the production of acetic acid. World J. Microbiol. Biotechnol. 2004, 20, 743-747. [CrossRef]

31. Moruno, E.G.; Delfini, C.; Pessione, E.; Giunta, C. Factors affecting acetic acid production by yeasts in strongly clarified grape musts. Microbios 1993, 74, 249-256. [PubMed]

32. Eglinton, J.M.; Heinrich, A.J.; Pollnitz, A.P.; Langridge, P.; Henschke, P.A.; de Barros Lopes, M. Decreasing acetic acid accumulation by a glycerol overproducing strain of Saccharomyces cerevisiae by deleting the ALD6 aldehyde dehydrogenase gene. Yeasts 2002, 19, 295-301. [CrossRef] [PubMed]

33. Marques, W.L.; Raghavendran, V.; Ugarte Stambuk, B.; Karoly Gombert, A. Sucrose and Saccharomyces cerevisiae: A relationship most sweet. FEMS Yeast Res. 2016, 16, fov107. [CrossRef]

34. Vucurovic, V.M.; Razmovski, R.N. Sugar beet pulp as support for Saccharomyces cerivisiae immobilization in bioethanol production. Ind. Crops Prod. 2012, 39, 128-134. [CrossRef]

35. Pavlečić, M.; Vrana, I.; Vibovec, K.; Ivančić Šantek, M.; Horvat, P.; Šantek, B. Ethanol production from different intermediates of sugar beet processing. Food Technol. Biotechnol. 2010, 48, 362-367.

36. Terebiznik, M.R.; Pilosof, A.M.R. Biomass estimation in solid state fermentation by modeling dry matter weight loss. Biotechnol. Tech. 1999, 13, 215-219. [CrossRef]

37. Bhargav, S.; Panda, B.P.M.; Ali, M.; Javed, S. Solid-state fermentation: An overview. Chem. Biochem. Eng. Q. 2008, 22, 49-70.

38. Steudler, S.; Böhmer, U.; Weber, J.; Bley, T. Biomass measurement by flow cytometry during solid-state fermentation of basidiomycetes. Cytom. Part A 2015, 87, 176-188. [CrossRef] [PubMed] 